\title{
Renal Amyloidosis in a Common Variable Immune Deficiency Patient with Autoimmune Complications
}

\author{
Otoimmun Komplikasyonlarla Seyreden Yaygın Değişken İmmün Yetmezlik Hastasında Renal \\ Amiloidoz
}

\author{
Gökhan AYTEKİN ${ }^{1}$ \\ (i) 0000-0002-9089-5914 \\ Fatih ÇÖLKESEN ${ }^{1}$ \\ (D) 0000-0002-9596-1773 \\ Eray YILDIZ ${ }^{1}$ \\ (D) 0000-0002-9596-1773 \\ Hacı Hasan ESEN ${ }^{2}$ \\ (1) 0000-0002-8559-2476 \\ Şevket ARSLAN ${ }^{1}$ \\ (i) 0000-0002-0343-0159
}

\begin{abstract}
Common variable immune deficiency (CVID) is a rare primary immunodeficiency disorder that is characterized by defective antibody production and inadequate B cell differentiation. While frequently recurrent respiratory tract infections are the most prominent clinical feature in CVID patients, CVID is a heterogeneous immune deficiency disorder that involves many systems and organs such as lymphoid hyperplasia, autoimmune cytopenia, chronic lung diseases, granulomatous diseases and susceptibility to malignancy. This may lead to delay in diagnosis and immunoglobulin replacement therapy, not being able to receive antibiotics at the appropriate dose and time, chronic inflammation, and therefore secondary amyloidosis. In this case report it is aimed to present a CVID patient with autoimmune complications and developing renal amyloidosis during follow-up.

Keywords: Common variable immune deficiency; renal amyloidosis; chronic inflammation.
\end{abstract}

${ }^{1}$ Necmettin Erbakan University Meram Faculty of Medicine Department of Allergy and Clinical Immunology, Konya, Turkey

ÖZ

Yaygın değişken immün yetmezlik (YDIY), bozulmuş antikor üretimi ve yetersiz B hücresi farklılaşması ile karakterize nadir görülen bir birincil immün yetmezlik tablosudur. Her ne ${ }^{2}$ Necmettin Erbakan University Meram kadar YDIY hastalarında sık tekrarlayan solunum yolu enfeksiyonları en belirgin klinik durum Faculty of Medicine Department of Pathology, Konya, Turkey olsa da; YDIY, lenfoid hiperplazi, otoimmün sitopeni, kronik akciğer hastalıkları, granülomatöz hastalıklar ve maligniteye yatkınlık gibi birçok sistem ve organı etkileyen heterojen bir immün sistem bozukluğudur. Bu durum, tanı ve immünoglobulin replasman tedavisinde gecikmeye, uygun dozda ve zamanda antibiyotik alınamamasına, kronik inflamasyona ve dolayısıyla sekonder amiloidoza yol açabilir. Bu vaka sunumunda, otoimmün komplikasyonla seyreden bir YDIY olgusu ve takip sırasında gelişen renal amiloidoz tablosunun sunulması amaçlanmıştır.

Anahtar kelimeler: Yaygın değişken immün yetmezlik; renal amiloidoz; kronik enflamasyon.

\section{INTRODUCTION}

Common variable immune deficiency (CVID) is a rare primary immune deficiency (PID) disorder that is thought to affect 1 in 25000 people, with defective antibody production characterized by inadequate B cell differentiation (1). Since the most prominent clinical feature in CVID patients is frequently recurrent respiratory tract infections, CVID is a heterogeneous disorder that involves many systems and organs such as lymphoid, autoimmune cytopenia, chronic lung diseases, granulomatosis diseases, and predisposition to malignancy $(2,3)$. The main laboratory finding is hypogammaglobulinemia. Amyloidosis is a heterogeneous group of diseases characterized by the accumulation of proteins, many of which are soluble in plasma, as abnormally insoluble fibrils in the extracellular space. Amyloidosis cases can be presented with very different clinical presentations depending on the localization, type and quantity of accumulated proteins. Accumulated amyloid fibrils are relatively stable and resistant to proteolysis. Due to their ability to bind Congo red dye, they show pathognomonic apple-green double refraction under polarized light (4). 
hypogammaglobulinemia date back half a century $(5,6)$, the diagnosis of amyloidosis is rarely defined in CVID patients because of insufficient level of PID awareness, delayed diagnosis and the necessity of an invasive procedure such as a biopsy to diagnose (7). Lederman et al. (8) showed none of 96 X-Linked Agammaglobulinemia (XLA) patients were found to have amyloidosis, while Hermaszewski et al. (1) stated that renal amyloidosis was found in only 2 patients out of 44 XLA patients in a study conducted in 1993. Mostly, because of the underlying inflammatory processes, amyloidosis has been reported in adult patients diagnosed with CVID, XLA and hypogammaglobulinemia. In this case we aimed to present a CVID patient with autoimmune complications and the progression of renal amyloidosis was determined.

\section{CASE REPORT}

For the first time in October 2013, 50 years old male patient consulted to the hospital with the complaint of weakness, fatigue, yellowing of the skin and darkening in the urine. The hemoglobin: $4.3 \mathrm{~g} / \mathrm{dl}$, mean corpuscular volume (MCV): $110.1 \mathrm{fl}$, indirect bilirubin: $6.6 \mathrm{mg} / \mathrm{dl}$, direct and indirect Coombs were (+) and splenomegaly (spleen: $155 \mathrm{~mm}$ ) was detected in laboratory results. Therefore, the patient hospitalized with a preliminary diagnosis of autoimmune hemolytic anemia and patient's complaints and laboratory findings were fixed with steroid treatment.

The patient, who did not have any complaints for about 4 years, was hospitalized again in May 2017 due to abdominal pain and low hemoglobin values. The patient was diagnosed as chronic autoimmune hemolytic anemia when hepatosplenomegaly was detected on physical examination, and hemoglobin: $6.4 \mathrm{~g} / \mathrm{dl}$, reticulocyte: 19.94\%, MCV: $106.7 \mathrm{fl}$, lactate dehydrogenase (LDH): $492 \mathrm{U} / \mathrm{L}$, indirect bilirubin: $3.03 \mathrm{mg} / \mathrm{dl}$.

In addition to hepatosplenomegaly, multiple lymph nodes with the largest one measuring 18x11 mm in the parailiac and paraaortic area in abdominal computed tomography (CT) and tubular bronchiectasis in the right middle lobe of the lung were detected. In positron emission tomography (PET)/CT scan, mild hypermetabolic lymph nodes have been reported throughout the body; primarily lymph node measuring $25 \times 10 \mathrm{~mm}$ in the right axillary region (SUV max: 4.83), $16 \mathrm{~mm}$ in diameter in the left axillary region (SUV max: 4.33) and approximately $16 \mathrm{~mm}$ in the right parailiac area in the intra-abdominal region (SUV max: 10.83). In the bone marrow examination performed with a preliminary diagnosis of lymphoma, it is reported that no CD34 + blastic cell increase was observed, and the samples did not have sufficient features for the diagnosis of lymphoma. As a result of the lymph node biopsy, it was reported that the lymph nodes were reactive and there was no staining in favor of amyloid with crystal violet and Congo red (Figure 1). In addition to these findings, the patient was consulted to our clinical immunology department upon the decrease in total protein and gamma globulin levels. The family history of the patient did not reveal any valuable information. There were no siblings or children who died at an early age. During the examinations, the patient had panhypogammaglobulinemia. Albuminuria was not detected in his 24-hour urine samples. In the peripheral lymphocyte subgroup analysis,
CD19 + B cell ratio was found to be low with $3.5 \%$ and IgD-IgM-CD27 + B cell ratio with $0.5 \%$ (Figure 2). Immunoglobulin analyses were repeated after 1 month and panhypogammaglobulinemia was observed to be persistent (Table 1). After the secondary reasons that would cause hypogammaglobulinemia were excluded, the patient was considered as lymphoid hyperplasia to secondary CVID and $400-600 \mathrm{mg} / \mathrm{kg}^{\wedge} 3$ weeks intravenous immunoglobulin (IVIG) treatment was started. Azithromycin $500 \mathrm{mg} /$ week was started for bronchiectasis. Blood samples sent for advanced genetic research.

After receiving immunoglobulin treatment for about 2 years, IgG levels started to decrease in the follow-ups. The patient was being investigated for secondary losses and no diarrhea was detected in the history. In the 24-hour urine, $1940 \mathrm{mg} /$ day albuminuria was detected. Kidney biopsy was conducted to the patient who was evaluated by the nephrology department, regarding etiology of albuminuria. Renal amyloidosis was detected as a result of biopsy (Figure 3). According to the recommendations of the nephrology department, ramipril $2.5 \mathrm{mg} 1 \times 1$ p.o. and colchicine $0.5 \mathrm{mg} 3 \times 1$ p.o. were initiated for renal proteinuria.

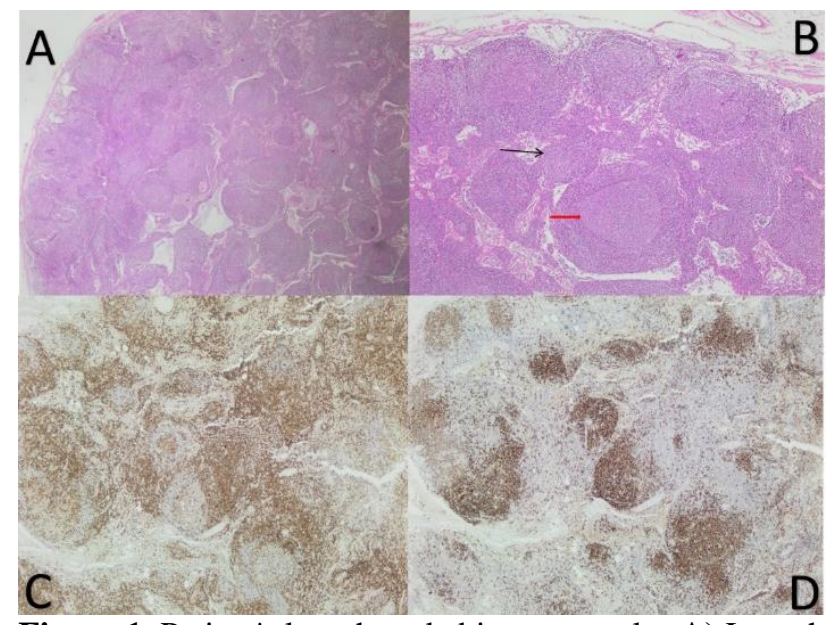

Figure 1. Patient's lymph node biopsy samples A) Lymph node surrounded by thin fibrous capsule, containing follicles of various shapes and sizes, (Hematoxylin-Eosin (HE) x20), B) Secondary follicle (red arrow) structures containing primary (black arrow) and germinal center (HEx20), C) Immunhistochemical CD3 staining (x40), D) Immunhistochemical CD23 staining (x40)
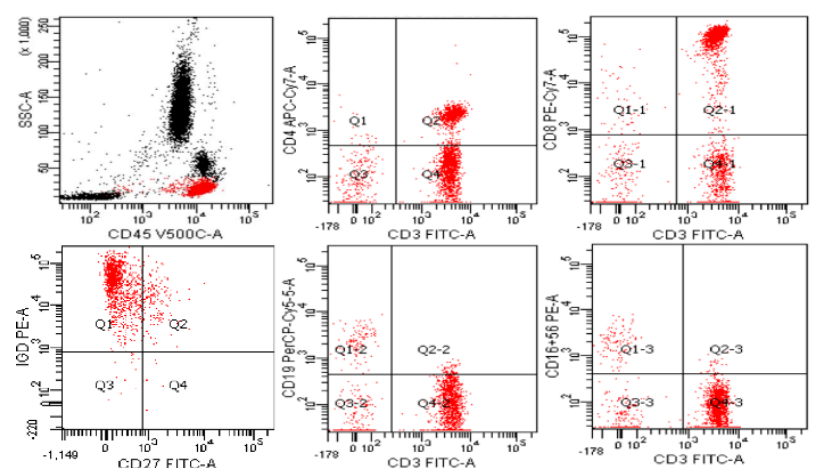

Figure 2. Patient's peripheral lymphocyte subgroup analysis 
Table 1. Patient's clinical and laboratory features

\begin{tabular}{|c|c|c|c|c|}
\hline & Normal values & October 2013 & May 2017 & May 2018 (with IVIG treatment) \\
\hline Hemoglobin & $12.1-17.2(\mathrm{~g} / \mathrm{dl})$ & 4.3 & 6.4 & 13.9 \\
\hline Reticulocytes & $\%$ & & 19.9 & \\
\hline $\mathrm{MCV}$ & 80-100 (fl) & 114 & 106.7 & 83.4 \\
\hline Neutrophils & $1500-7.300\left(/ \mathrm{mm}^{3}\right)$ & 6400 & 6550 & 10090 \\
\hline Lymphocytes & $800-5500\left(/ \mathrm{mm}^{3}\right)$ & 2310 & 5790 & 4490 \\
\hline Platelets & $150-400\left(1000 \mathrm{x} / \mathrm{mm}^{3}\right)$ & 229 & 220 & 221 \\
\hline Total/indirect bilirubin & $(\mathrm{mg} / \mathrm{dl})$ & 7.2/6.6 & 3.6/3.03 & $1.17 / 0.37$ \\
\hline LDH & $135-225 \mathrm{U} / \mathrm{L}$ & 452 & 492 & 237 \\
\hline Indirect Coombs & & positive & positive & \\
\hline Direct Coombs & & IgG-pos & IgG-pos & \\
\hline $\operatorname{IgG}$ & $7-17(\mathrm{~g} / \mathrm{L})$ & & 1.35 & $1.69 \rightarrow 1.89 \rightarrow 4.35$ \\
\hline $\operatorname{IgM}$ & $0.4-2.3(\mathrm{~g} / \mathrm{L})$ & & 0.19 & $\mathbf{0 . 1 8 6}$ \\
\hline $\operatorname{Ig} \mathrm{A}$ & $0.7-4(\mathrm{~g} / \mathrm{L})$ & & 0.261 & 0.261 \\
\hline $\operatorname{IgE}$ & $0-100(\mathrm{~g} / \mathrm{L})$ & & & \\
\hline IgG1 & $4.05-10.11(\mathrm{~g} / \mathrm{L})$ & & 0.856 & \\
\hline $\operatorname{IgG} 2$ & $1.69-7.86(\mathrm{~g} / \mathrm{L})$ & & 0.335 & \\
\hline $\mathrm{IgG} 3$ & $0.11-0.85(\mathrm{~g} / \mathrm{L})$ & & 0.0345 & \\
\hline IgG4 & $0.03-2.01(\mathrm{~g} / \mathrm{L})$ & & 0.0543 & \\
\hline Tetanus antibody & $\geq 0.5(\mathrm{IU} / \mathrm{ml})$ & & 0.01 & \\
\hline Anti-Hepatitis B & $0-10 \mathrm{mIU} / \mathrm{ml}$ & & 33.13 & \\
\hline $\mathrm{CD}^{+} \mathrm{T}$ cells $(\%)$ & $48-82.6 \%$ & & 89 & 91 \\
\hline $\mathrm{CD} 4^{+} \mathrm{T}$ cells $(\%)$ & $23-52.6 \%$ & & 27.6 & 27 \\
\hline $\mathrm{CD}^{+} \mathrm{T}$ cells $(\%)$ & $12.8-40.2 \%$ & & 60.6 & 61 \\
\hline CD19+ B cells $(\%)$ & $6.3-20.8 \%$ & & 3.5 & 3 \\
\hline CD $16-56^{+} \mathrm{T}$ cells $(\%)$ & $5-31.3 \%$ & & 3.1 & 3 \\
\hline $\begin{array}{l}\mathrm{IgD}^{+} \operatorname{IgM} \mathrm{CD}^{+} \mathrm{CD} 7^{-} \mathrm{B} \text { cells }(\%) \\
\text { Naive B cells }\end{array}$ & & & 85.3 & 97 \\
\hline $\mathrm{IgD}^{-} \operatorname{IgM} \mathrm{CDD}^{-} 7^{+} \mathrm{B}$ cells $(\%)$ & & & & 08 \\
\hline Switched Memory B cells & & & 0.5 & 0.8 \\
\hline Isohemagglutinin & $\geq 1 / 4$ & Anti-A: $1 / 4$ & & \\
\hline Anti-HIV & & $(-)$ & $(-)$ & \\
\hline
\end{tabular}

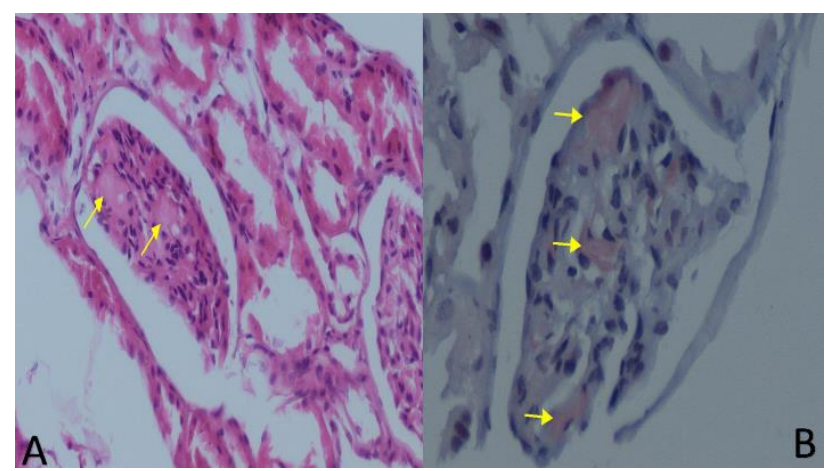

Figure 3. Patient's renal biopsy samples A) Amyloid deposits in glomerulus (HEx10), B) Amyloid deposits in glomerulus (Congo red x20)

\section{DISCUSSION}

While recurrent respiratory tract infections are the most prominent clinical feature in CVID patients, CVID is a heterogeneous immune deficiency disorder that involves many systems and organs such as lymphoid hyperplasia, autoimmune cytopenia, chronic lung diseases, granulomatous diseases, and susceptibility to malignancy $(2,3,9)$. This may lead to delay in diagnosis and immunoglobulin replacement therapy, not being able to receive antibiotherapy at the appropriate dose and time, chronic inflammation, and therefore secondary amyloidosis (10). In addition, treatment and follow-up incompatibility and presence of bronchiectasis also contribute to the development of amyloidosis (11). Renal amyloidosis often presents itself with nephrotic albuminuria and renal insufficiency. Although frequent infections and increased autoimmunity are well defined and expected complications in CVID, renal pathologies are rarely reported in this patient group, and current literature are mostly in the form of case reports (1,11-15).

Meysman et al. (16) reported XLA patient with persistent diarrhea due to systemic amyloidosis in 1993. In 1996, Kotilainen et al. (17) reported a case of nephrotic syndrome due to systemic amyloidosis associated with frequent infections and inadequate immunoglobulin replacement in a 49-year-old patient who was followed for hypogammaglobulinemia for 18 years. Due to the nephrotic syndrome of the patient, higher dose and more frequent intervals of IVIG infusion were required for infection control. In our patient, nephrotic albuminuria was detected after the diagnosis of CVID and this prevented the effective and stable serum immunoglobulin levels by causing renal loss of the replaced immunoglobulins. It may be beneficial to undergo subcutaneous replacement in cases of gastrointestinal or renal loss for the patients receiving immunoglobulin replacement therapy (18). 
Amyloidosis can be accumulated in all body organs and systems and the kidneys are the most frequently affected organs, but renal amyloidosis is a rare clinical disorder. Esteve et al. (19) conducted a study for 12-year survey in Spain and they found the incidence of AA amyloidosis to be 12.2 per million population. Arslan et al. (12) presented the first case of renal and pulmonary amyloidosis for CVID patients in 2014. In clinical follow-up, patient did not comply with immunoglobulin replacement and prophylactic antibiotic treatment so the presentation of renal amyloidosis causing abdominal acid, pleural effusion, and pretibial edema was poorly defined. In same patient, pulmonary amyloidosis is diagnosed with biopsy applied within 1 year and associated severe lung complications and pulmonary hypertension was progressed (12).

Balwani et al. (20) reported a patient who has been suffering from respiratory infection and diarrhea for twenty years, receiving at least 1 hospitalization history every year for pneumonia, 9 months of anti-tuberculosis treatment due to pulmonary tuberculosis. After developing nephrotic albuminuria due to renal amyloidosis, hypoalbuminemia and pedal oedema, this patient could be diagnosed with CVID. Renal amyloidosis has been associated with previous tuberculosis infection and chronic inflammation due to recurrent lung infections. The bronchiectasis present in our patient can also be accepted as an indication that the patient has been exposed to chronic persistent inflammation for a long time. In the same year, Esenboğa et al. (11) reported a patient with chronic diarrhea, frequent sinopulmonary infections, and hypogammaglobulinemia and diagnosed with CVID. Although rectal and gingival biopsies are negative in terms of amyloidosis, amyloidosis was detected in renal biopsy. In conclusion, even if immunoglobulin replacement therapy reduces the frequency of infection; controlling of infections, prophylactic antibiotic therapy, immunoglobulin replacement at appropriate doses and intervals, and regular clinical follow-up are very important for preventing amyloidosis, which is a rare but mortal complication in CVID patients. In addition, sudden reductions in serum IgG levels, difficulties in obtaining stable and effective trough IgG levels should suggest possible secondary losses in these patients, and clinicians should not ignore the possibility of renal amyloidosis in these patients.

Informed consent was obtained from the patient.

\section{REFERENCES}

1. Hermaszewski RA, Webster AD. Primary hypogammaglobulinaemia: a survey of clinical manifestations and complications. Q J Med. 1993;86(1):31-42.

2. Cunningham-Rundles $\mathrm{C}$, Bodian $\mathrm{C}$. Common variable immunodeficiency: clinical and immunological features of 248 patients. Clin Immunol. 1999;92(1):34-48.

3. Spickett GP, Farrant J, North ME, Zhang JG, Morgan L, Webster AD. Common variable immunodeficiency: how many diseases? Immunol Today. 1997;18(7):325-8.

4. Lachmann HJ, Hawkins PN. Systemic amyloidosis. Curr Opin Pharmacol. 2006;6(2):214-20.

5. Strachan RW, Gillanders LA. A case of primary acquired hypogammaglobulinaemia with pernicious anaemia and amyloidosis: demonstrated at the
Postgraduate Medical School of London. Br Med J. 1965;1(5426):35-8.

6. Gaffney EF, Lee JC. Systemic amyloidosis and hypogammaglobulinemia. Arch Pathol Lab Med. 1978;102(11):558-9.

7. Borte S, Celiksoy MH, Menzel V, Ozkaya O, Ozen FZ, Hammarström L, et al. Novel NLRP12 mutations associated with intestinal amyloidosis in a patient diagnosed with common variable immunodeficiency. Clin Immunol. 2014;154(2):105-11.

8. Lederman HM, Winkelstein JA. X-linked agammaglobulinemia: an analysis of 96 patients. Medicine (Baltimore). 1985;64(3):145-56.

9. Aytekin G, Çölkesen F, Yıldız E, Arslan S. Risk factors of bronchiectasis in adult patients with common variable immunodeficiency. Asthma Allergy Immunol. 2019;17(3):160-5.

10. Urschel S, Kayikci L, Wintergerst U, Notheis G, Jansson A, Belohradsky BH. Common variable immunodeficiency disorders in children: delayed diagnosis despite typical clinical presentation. J Pediatr. 2009; 154(6):888-94.

11. Esenboga S, Çagdas Ayvaz D, Saglam Ayhan A, Peynircioglu B, Sanal O, Tezcan I. CVID associated with systemic amyloidosis. Case Reports Immunol. 2015;2015:879179.

12. Arslan S, Ucar R, Yavsan DM, Esen H, Maden E, Reisli I, et al. Common variable immunodeficiency and pulmonary amyloidosis: a case report. J Clin Immunol. 2015;35(4):344-7.

13. Aydin Z, Gursu M, Ozturk S, Kilicaslan I, Kazancioglu R. A case of primary immune deficiency presenting with nephrotic syndrome. NDT Plus. 2010;3(5):456-8.

14. Turkmen K, Anil M, Solak Y, Atalay H, Esen H, Tonbul HZ. A hepatitis C-positive patient with new onset of nephrotic syndrome and systemic amyloidosis secondary to common variable immunodeficiency. Ann Saudi Med. 2010;30(5):401-3.

15. Kadiroğlu AK, Yıldırım Y, Yılmaz Z, Kayabaşı H, Avc1 Y, Y1ldırım MS, et al. A rare cause of secondary amyloidosis: common variable immunodeficiency disease. Case Rep Nephrol. 2012;2012:860208.

16. Meysman M, Debeuckelaer S, Reynaert H, Schoors DF, Dehou MF, Van Camp B. Systemic amyloidosisinduced diarrhea in sex-linked agammaglobulinemia. Am J Gastroenterol. 1993;88(8):1275-7.

17. Kotilainen P, Vuori K, Kainulainen L, Aho H, Saario $\mathrm{R}$, Asola M, et al. Systemic amyloidosis in a patient with hypogammaglobulinaemia. $\mathrm{J}$ Intern Med. 1996;240(2):103-6.

18. Aytekin G, Çölkesen F, Ardeniz O, Çalışkaner A. Successful immunoglobulin replacement with subcutaneous immunoglobulin therapy in a patient with primary intestinal lymphangiectasia. Asthma Allergy Immunol. 2019;17(1):57-60.

19. Esteve V, Almirall J, Ponz E, García N, Ribera L, Larrosa M, et al. [Renal involvement in amyloidosis. Clinical outcomes, evolution and survival]. Nefrologia. 2006;26(2):212-7.

20. Balwani MR, Kute VB, Shah PR, Wakhare P, Trivedi HL. Secondary renal amyloidosis in a patient of pulmonary tuberculosis and common variable immunodeficiency. J Nephropharmacol. 2015;4(2):69-71. 